\title{
Strategi Humas Universitas Negeri Makassar Dalam Meningkatkan Citra Positif Masyarakat
}

\author{
Risma Niswaty, Sri Wulandari, Sirajuddin Saleh, Muh. Rizal S \\ Universitas Negeri Makassar \\ Email: risma.niswaty@gmail.com
}

(Diterima: 17-Juli-2018; di revisi: 14-Agustus-2018; dipublikasikan: 30-Desember-2018)

\begin{abstract}
ABSTRAK
Penelitian ini bertujuan untuk mengetahui strategi Humas Universitas Negeri Makassar dalam meningkat kan citra positif Universitas Negeri Makassar di masyarakat. Untuk mengetahui tujuan tersebut maka peneliti menggunakan jenis penelitian deskriptif kualitatif. Informan pada penelitian ini sebanyak lima orang dengan menggunakan teknik pengumpulan data yang dilakukan melalui observasi, wawancara dan dokumentasi. Data yang diperoleh dari hasil penelitian diolah dengan menggunakan teknik analisis data yang terdiri atas reduksi data, penyajian data dan penarikan kesimpulan. Hasil penelitian menunjukkan bahwa Humas menyusun strategi agar fungsi tersebut dapat berjalan sesuai dengan tujuan Universitas Negeri Makassar diantaranya, berusaha menciptakan iklim yang kondusif antara institusi dengan publik untuktujuanbersama, melakukanpendekatan yang persuasifdanedukatifdenganpublik, berusaha menciptakan komunikasi dua arah dengan menyebarkan informasi dari institusi kepada pihak publik yang bersifat mendidik dan memberikan penerangan, agar tercipta saling pengertian, menghargai, pemahaman dan juga berupaya membina hubungan yang harmonis antara organisasi dengan berbagai kalangan, baik hubungan kedalam maupun hubungan keluar untuk meningkatkan kerjasama. Humas berusaha memasyarakatkan misi Universitas Negeri Makassar agar diterima atau mendapat dukungan dari ma syarakat / publik.
\end{abstract}

Kata kunci: Strategi, Citra

\section{ABSTRACT}

This study aims to determine the public relations strategy of Makassar State University in increasing the positive image of Makassar State University in the community. To find out these objectives, the researchers used a type of qualitative descriptive research. The informants in this study were as many as five people using data collection techniques carried out through observation, interviews and documentation. Data obtained from research results are processed using data analysis techniques consisting of data reduction, data presentation and conclusion drawing. The results showed that Public Relations devised a strategy so that the function could run in accordance with the objectives of Makassar State University, among others, trying to create a conducive climate between institutions and the public in order to do persuasive and educative approaches to the public, trying to create two-way communication by disseminating information from institutions to public parties. educate and provide information, in order to create mutual understanding, respect, understanding and also strive to foster harmonious relations between organizations and various groups, both in and out relations to enhance cooperation. Public Relations seeks to socialize the Makassar State University mission to be accepted or received support from the public / public.

Keywords: Strategy, Image

Copyright (C) 2018 Universitas Negeri Makassar. This is an open access article under the CC BY license (http://creativecommons.org/licenses/by/4.0/) 


\author{
100 Jurnal Administrare: Jurnal Pemikiran Ilmiah dan Pendidikan Administrasi Perkantoran \\ Vol. 5, No. 2, Juli - Desember 2018, Hal 99-104
}

\title{
PENDAHULUAN
}

Pendidikan merupakan salah satu hal terpenting bagi setiap orang (Brooks-Lewis, 2012; Fernández, 2017; Riley \& Riley, 2017; Sandell et al., 2016). Demi mewujudkan UndangUndang Dasar 1945 dalam mencerdaskan kehidupan bangsa. Seiring berkembangnya waktu kesadaran masyarakat Indonesia terhadap pendidikan mulai tumbuh mulai yang dari tingkat dasar hingga ke perguruan tinggi. Perguruan tinggi bertujuan untuk menghasilkan sumber daya manusia yang siap mengabdikan dirinya di tengah masyarakat guna mewujudkan kemajuan bangsa, baik menjadi tenaga profesional hingga lulusan yang mampu menciptakan lapangan pekerjaan sendiri (Amanda, Salam, \& Saggaf, 2017) (Akib, Guntur, \& Salam, 2016; Nasrullah, Ilmawati, Saleh, Niswaty, \& Salam, 2018; Saggaf, Akib, Salam, Baharuddin, \& Kasmita, 2018; Salam, Zunaira, \& Niswaty, 2016).

Kemajuan bangsa dimasa yang akan datang bergantung pada mutu pendidikan generasi muda saat ini. Mutu perguruan tinggi menjadi salah satu alasan calon mahasiswa memilih perguruan tinggi namun tidak terlepas dari bagaimana perguruan tinggi menampilkam kelebihan-kelebihan untuk meningkatkan nilai tawar kepada masyarakat khususnya calon mahasiswa.Menampilkan citra positif bagi suatu perguruan tinggi merupakan keharusan yang penting, mengingat persaingan yang dihadapi dunia pendidikan indonesia saat ini sangat kompetitif terlebih agar dapat menarik perhatian dan membentuk persepsi masyarakat kepada perguruan tinggi tersebut.

Hubungan masyarakat, atau sering disingkat Humas (public relations) merupakan bagian dari perusahaan, organisasi maupun intitusi yang berperan dalam menampilkan citra.humas menjadi penting karena bertugas untuk menampilkan berbagai kelebihan organisasinya demi menarik perhatian khalayak.Implementasi dari strategi humas diharapkan dapat membentuk citra positif yang akan menarik perhatian khalayak dan juga mencapai tujuan dari perguruan tinggi.Fungsi utama humas adalah menumbuhkan dan mengembangkan hubungan baik antara organisasi dengan publiknya, internal maupun eksternal dalam rangka menanamkan pengertian, menumbuhkan motivasi dan partisipasi publik dalam upaya menciptakan opini publik.

Kode etik Humas memberikan pahaman bahwa jika menghadapi situasi yang genting seperti timbul masalah, konflik, atau pertikaian maka seorang humasatau publik relations wajib untuk menjelaskan secara jujur dan terbuka mengenai masalah tersebut (Byrum, 2017; Tao \& Kim, 2017; Watson, 2014; Yang, Taylor, \& Saffer, 2016). Univeristas Negeri Makassar merupakan salah satu perguruan tinggi negeri di Makassar yang tidak terlepas dari masalahmasalah yang dapat mempengaruhi citra perguruan tinggi tersebut dimasyarakat.Berdasarkan fenomena yang terjadi di Universitas Negeri Makassar tersebut maka peneliti bermaksud mengkaji tentang Strategi Humas dalam Meningkatkan Citra Positif Universitas Negeri Makassar di Masyarakat.

Menurut Undang-Undang Republik Indonesia Nomor 25 Tahun 2009 Tentang Pelayanan Publik, Penyelenggaraan pelayanan publik berasaskan kepentingan umum, kepastian hokum, kesamaan hak, keseimbangan hak dan kewajiban, keprofesionalan, partisipatif, persarnaan perlakuan/ tidak diskriminatif, keterbukaan, akuntabilitas, fasilitas dan perlakuan khusus bagi kelompok rentan, ketepatan waktu, dan kecepatan, kemudahan, dan keterjangkauan. 


\section{METODE}

Jenis Penelitian digunakan pada penelitian ini adalah deskriptif kualitatif dikarenakan penelitian ini berusaha menghasilkan temuan melalui berbagai cara pengumpulan data. Penelitian in berfokus pada strategi yang dilakukan oleh bagian Humas sehingga penelitian ini dilakukan di Bagian Humas Universitas Negeri Makassar. Tahap-tahap penelitian ini ialah, tahap pra-lapangan, tahap pekerjaan lapangan, memasuki lokasi penelitian, berperan serta sambil mengumpulkan data.

Penelitian ini memilih lima informan untuk mendapatkan data yang valid dan peneliti menentukan informan dari Humas sebanyak dua orang dan dari masyarakat sebanyak 3 orang dalam hal ini dosen, mahasiswa dan juga orangtua mahasiswa.

Instrumen utama dalam penelitian ini adalah peneliti sendiri sebagai pengumpul data. Untuk mendukung tugas dalam penelitian ini, maka digunakan alat bantu berupa pedoman wawancara, selain itu untuk merekam peristiwa dan wawancara dalam penelitian ini digunakan HP (Handphone). Adapun teknik pengumpulan data yang digunakan dalam penelitian ini adalah observasi, wawancara, dan dokumentasi.

Pengecekan keabsahan data dalam penelitian kualitatif ini meliputi uji kredibilitas (credibilityi), uji dependabilitas (dependability), uji komfirmabilitas (comfirmability). Dalam menganalisis hasil penelitian digunakan pengumpulan data, reduksi data, penyajian data, dan penarikan kesimpulan.

\section{HASIL PENELITIAN DAN PEMBAHASAN}

Penelitian ini membahas mengenai strategi Humas Universitas Negeri Makassar dalam meningkatkan citra positif Universitas Negeri Makassar di masyarakat berdasarkan empat indikator yaitu pendekatan operasional, pendekatan persuasif dan edukatif, pendekatan tanggung jawab sosial, dan pendekatan kerjasama.

\section{Pendekatan Operasional}

1. Menemukan problem

Humas Universitas Negeri Makassar dalam strategi untuk meningkatkan citra positif menjadikan proses penemuan problem/ fact finding sebagai salah satu cara yang dilakukan dalam menjalankan kerja-kerja kehumasan. Dengan penemun problem maka Humas dapat mengetahui secara persis siapa publik yang dihadapi, segmentasinya, opininya, dan harapannya. Selain itu penemuan masalah dapat mempengaruhi tindak lanjut yang akan dilakukan oleh Humas dalam menyelesaikan masalah di Universitas Negeri Makassar.

\section{Perencanaan dan pemrograman}

Dalam perencanaan dan pemrogramman, berupaya membina hubungan yang harmonis dengan berbagai kalangan baik itu hubungan kedalam (internal relations) maupun hubungan 

102 Jurnal Administrare: Jurnal Pemikiran Ilmiah dan Pendidikan Administrasi Perkantoran Vol. 5, No. 2, Juli - Desember 2018, Hal 99-104

keluar (eksternal relations) hal ini dilakukan dengan keterampilan komunikasi yang dilakukan Humas, selain itu juga sebagai mediator dalam menyalurkan kepentingan internal dan eksternal.

3. Mengambil tindakan dan komunikasi

Berupaya membangun komunikasi dengan pihak internal yakni berkisar pada agenda/kegiatan yang dilakukan hal ini agar dapat mmbina hubungan antara pemimpin dengan pihak internal Universitas Negeri Makassar sedangkan dalam komunikasi dengan pihak eksternal, dengan kegiatan publikasi selain itu juga menjalin hubungan yang bersifat partisipatif dengan pihak eksternal salah satunya ialah dengan media yang bekerjasama dengan Universitas Negeri Makassar.

\section{Evaluasi program}

Humas dalam penentuan strategi menjadikan evaluasi sebagai proses yang penting dilakukan, dalam hal ini Humas Universitas Negeri Makassar melakukan evaluasi secara berkala agar dapat menjadi dasar untuk melaksansakan tindak lanjut dan untuk melakukan pengambilan keputusan berikutnya.

\section{Pendekatan Persuasif dan Edukatif}

Universitas Negeri Makassar dalam membangun komunikasi timbal balik dengan masyarakat baik internal maupun eksternal dalam upaya meningkatkan citra positif, Humas memanfaatkan media untuk penyebaran informasi selain itu Humas juga memiliki program yang bertujuan untuk menciptakan hubungan yang harmonis dengan masyarakat internal maupun eksternal Universitas Negeri Makassar, namun dalam hal ini Humas diharapkan juga bisa mengotimalkan perannya sebagai komunikator dan mediator dalam menjalankan tugastugasnya dalam hal ini untuk kepentingan semua pihak, bukan hanya pimpinan Universitas tetapi juga pihak yang lain yakni dosen, pegawai, mahasiswa dan juga masyarakat.

\section{Pendekatan Tanggung Jawab Sosial}

Humas Universitas Negeri Makassar dalam melaksanakan tanggungjawab sosialnya menyusun program dimana menjadikan masyarakat sebagai sasarannya, salah satunya ialah pemberitaan atau penyebaran informasi mengenai kegiatan kampus agar memberikan penerangan kepada masyarakat luas tentang keadaan Universitas Negeri Makassar, selain itu Humas juga berupaya menyusun program yang bertujuan untuk membangun hubungan yang harmonis dengan masayarakat baik internal maupun eksternal.

\section{Pendekatan Kerjasama}

Humas Universitas Negeri Makassar dalam proses kerja sama baik dengan publik internal dan eksternal lebih memanfaatkan bagaimana membangun komunikasi dan juga memanfaatkan perkembangan teknologi informasi. Agar menciptakan komunikasi dua arah (timbal balik) 
Risma Niswaty, Sri Wulandari, Sirajuddin Saleh, Muh. Rizal S; Strategi Humas... 103

dengan menyebarkan informasi dari institusi kepada pihak publik yang bersifat mendidik, dan memberikan penerangan, agar tercipta saling pengertian, menghargai, pemahaman dan sebagainya. Hal ini dilakukan oleh Humas sesuai dengan membagikan informasi kepada berbagai pihak mengenai tujuan yang hendak dicapai dan juuga melaksanakan kajian, analisis evaluasi dan pelaporan kegiatan bidang infromasi dan pemberitaan, pengelolaan pengaduan serta protokol dan dokumentasi.

\section{SIMPULAN}

Berdasarkan hasil penelitian mengenai strategi Humas Universitas Negeri Makassar,dalam menjalankan fungsi sebagai bagian yang memegang peranan penting dalam meningkatkan citra positif Universitas Negeri Makassar, Humas menyusun strategi agar fungsi tersebut dapat berjalan sesuai dengan tujuan Universitas Negeri Makassar diantaranya, berusaha menciptakan iklim yang kondusif antara institusi dengan publik untuk tujuan bersama, melakukan pendekatan yang persuasif dan edukatif dengan public, Berusaha menciptakan komunikasi dua arah dengan menyebarkan informasi dari institusi kepada pihak publik yang bersifat mendidik dan memberikan penerangan, agar tercipta saling pengertian, menghargai, pemahaman,dan sebagainya. Dan Berupaya membina hubungan yang harmonis antara organisasi dengan berbagai kalangan,baik hubungan kedalam maupun hubungan keluar untuk meningkatkan kerjasama. Humas berusaha memasyarakatkan misi Universitas Negeri Makassar agar diterima atau mendapat dukungan dari masyarakat / publik.

\section{DAFTAR PUSTAKA}

Akib, H., Guntur, M., \& Salam, R. (2016). Civitas Academic Perception of "Blissful Services" for Recipient Postgraduate Program State University of Makassar, Indonesia. In International Conference on Public Organization VI (ICONPO VI) (pp. 340-350). Thammsat University, Tha Prachan Campus.

Amanda, M. O., Salam, R., \& Saggaf, S. (2017). Pengaruh Supervisi Kepala Sekolah Terhadap Kinerja Guru Di SMK Negeri 1 Bungoro Kabupaten Pangkep. In Prosiding Seminar Nasional Himpunan Sarjana Ilmu-ilmu Sosial (Vol. 2, pp. 149-154).

Brooks-Lewis, K. A. (2012). Sharing Roles in the Classroom: Everyone is a Teacher, Everyone is a Learner. Procedia - Social and Behavioral Sciences, 46, 4962-4966. https://doi.org/https://doi.org/10.1016/j.sbspro.2012.06.368

Byrum, K. (2017). The European right to be forgotten: A challenge to the United States Constitution's First Amendment and to professional public relations ethics. Public Relations

Review,

43(1),

102-111. 
104 Jurnal Administrare: Jurnal Pemikiran Ilmiah dan Pendidikan Administrasi Perkantoran Vol. 5, No. 2, Juli - Desember 2018, Hal 99-104

https://doi.org/https://doi.org/10.1016/j.pubrev.2016.10.010

Fernández, M. T. (2017). Attitudes toward Inclusive Education and Practical Consequences in Final Year Students of Education Degrees. Procedia - Social and Behavioral Sciences, 237, 1184-1188. https://doi.org/https://doi.org/10.1016/j.sbspro.2017.02.187

Nasrullah, M., Ilmawati, I., Saleh, S., Niswaty, R., \& Salam, R. (2018). Pengaruh Fasilitas Perpustakaan terhadap Minat Baca Siswa di SMK Negeri 4 Makassar. Jurnal Ad'ministrare, 5(1), 1-6.

Riley, B. A., \& Riley, G. (2017). Innovation in graduate medical education - using a competency based medical education curriculum. International Journal of Osteopathic Medicine, 23, 36-41. https://doi.org/https://doi.org/10.1016/j.ijosm.2016.07.001

Saggaf, M. S., Akib, H., Salam, R., Baharuddin, A., \& Kasmita, M. (2018). The Quality Analysis Of Academic Services.

Salam, R., Zunaira, Z., \& Niswaty, R. (2016). Meningkatkan Hasil Belajar Membuat Dokumen melalui Penggunaan Model Pembelajaran Kooperatif Tipe Make a Match (Mencari Pasangan). Jurnal Office, 2(2), 173-180.

Sandell, M., Mikkelsen, B. E., Lyytikäinen, A., Ojansivu, P., Hoppu, U., Hillgrén, A., \& Lagström, H. (2016). Future for food education of children. Futures, 83, 15-23. https://doi.org/https://doi.org/10.1016/j.futures.2016.04.006

Tao, W., \& Kim, S. (2017). Application of two under-researched typologies in crisis communication: Ethics of justice vs. care and public relations vs. legal strategies. Public Relations Review, 43(4), 690-699. https://doi.org/https://doi.org/10.1016/j.pubrev.2017.06.003

Watson, T. (2014). IPRA Code of Athens-The first international code of public relations ethics: Its development and implementation since 1965. Public Relations Review, 40(4), 707-714. https://doi.org/https://doi.org/10.1016/j.pubrev.2013.11.018

Yang, A., Taylor, M., \& Saffer, A. J. (2016). Ethical convergence, divergence or communitas? An examination of public relations and journalism codes of ethics. Public Relations Review, 42(1), 146-160. https://doi.org/https://doi.org/10.1016/j.pubrev.2015.08.001 